\title{
Microbial technology for metal recovery from e-waste printed circuit boards
}

\begin{abstract}
End-of-Life Electrical and Electronic Equipments commonly know as e-waste is an emerging problem with developed as well as developing nations. Our obsession on electrical and electronic equipments, the unquenchable desire for latest devices and rapid advances in technology has resulted in the world wide generation of huge amount of e-waste. Printed circuit boards (PCBs), the core processing unit of electronic devices contain complex mixture of ceramics, metals and polymers. PCBs are considered as secondary source of several metals. Only a small fraction of this being treated or recycled properly; lion share of e-waste is dumped as landfills or incinerated. Till date no standard eco-friendly technique is available for their safe disposal. In recent decades significant attempts have been done for developing pyrometallurgical and hydrometallurgical technology for recovery of metals from PCBs, but these processes are also non sustainable due to secondary pollution they create and they are cost intensive. Microbial biotechnology, based mainly on the potential of microorganisms to generate lixiviants which mobilize metals from PCBs. Iron and sulphur oxidizing bacteria generate ferric iron and protons which extract several metals in aqueous phase. Cynogenic microorganisms are effectively used extraction of gold and silver from PCBs. Some fungi are also reported for metal solubilisation from PCBs by generating organic acids. This technology is considered a novel approach to mobilize metals from various types of PCBs. The main advantage of microbial technology would it can work with dilute waste streams, work at ambient temperatures and pressures, it is cost effective, reduce environmental impacts and generate minimum secondary waste. Thus, this chapter explores furnish and the details on microorganism based technology for extractions of base and precious metals from e-waste PCBs.
\end{abstract}

Keywords: biomining, e-Waste, PCBs, bioleaching, microbes
Volume 6 Issue 4 - 2018

\author{
Shailesh R Dave,' Asha B Sodha, ${ }^{2}$ Devayani R \\ Tipre $^{2}$ \\ 'Department of Forensic Science, School of Sciences, Gujarat \\ University, India \\ ${ }^{2}$ Department of Microbiology and Biotechnology, School of \\ Sciences, Gujarat University, India
}

Correspondence: Shailesh R Dave, Department of Forensic Science, School of Sciences, Gujarat University, India, Email shaileshrdave@yahoo.co.in

Received: May 26, 2018 | Published: July 23, 2018

\section{Introduction}

Rapid urbanization, industrialization, and population growth have resulted in increased demand of electronic and electrical gadgets. With fast technological advancement and development, due to the demand of people, industries are now manufacturing novel, superior and smart electronic and electrical equipments (EEEs) at an alarming rate. More and more EEEs products are produced, purchased, used and discarded resulting in the generation of huge amount of waste electronic and electrical equipments (WEEEs). ${ }^{1}$ The electronic waste (e-Waste) normally consist of small and large equipment such as LED lamps, cell phones, smart mobile phones, superior televisions, refrigerators, printers, driers, temperature exchangers as well as advance computing devices. ${ }^{2}$ Due to the fast advancement in technology and tremendous market growth most of these electronic and electric material have very short life span, which resulted in the fastest accumulation in e-Waste. ${ }^{3}$ Broadly, the end of life electrical and electronic equipments without intent of reuse is considered as e-Waste. As per the information available in literature in 2014, about 41.8 million tons of e-Waste generated globally and as per the estimation e-Waste is growing at the rate of $4-5 \%$ annually, which leads to about 49.8 million tons of e-Waste generation in $2018 .{ }^{4}$ The large amounts of complex and diverse e-Waste generated have adverse impact on environment as well as human being, if they are not properly managed. Unfortunately there is no proper system to collect, store, transport, treat, and disposal of e-Waste. Thus, it has become major issue of concern for the industries, government and non-government organization and even for the public to protect the environment from the hazardous effect of improperly managed e-Waste. ${ }^{5}$ Most of us know that e-Waste has been accumulated since many years, but their devastating environmental effects is realized recently, which has created keen awareness in the scientific community as well as in common people throughout the world and it has forced concerned peoples for their proper treatment. E-Waste has been accumulated since many years; contain several hazardous organic pollutant as well as considerable amount of base, precious and rare earth metals. ${ }^{6}$ The core component of all electronic and many electrical equipment is printed circuit boards (PCBs), which is used for smooth, fast and convenient functioning of small to large electronic devices. PCBs contain several metals as well as various organic pollutants. Thus, it cannot be dumped as landfill or incinerated. However, incineration and land filling are the common method adapted for e-Waste management, which leads to the release of toxic gases in atmosphere and highly harmful metals in soil and ground waters. These pollutants will accumulate and transport in plant systems, which ultimately reach to animals and human. ${ }^{7,8}$ Due to this awareness e-Waste management has become a vital and significant field of research throughout the world. The current chapter mainly focus on bio-treatment of PCBs with special reference to extraction of metals from waste PCBs by using microbial technology. Types of microorganisms involved in the metal solubilisation process and major mechanisms of metal extractions are illustrated.

\section{e-Waste and printed circuit boards (PCBs)}

Asian countries like India and China are the major countries, which get the e-Waste from all over the world for recycling purpose as the developing countries have less legislation rules for disposal. ${ }^{9}$ There are several definitions for e-Waste, but the simplest definition for e-Waste is "any broken or unwanted electronic and electrical appliances/equipments". According to European Union, ${ }^{10}$ any 
appliance using an electric power supply that has reached its endof-life would come under e-Waste. All the electronic appliances and most of the electric equipments have printed circuit boards (PCBs) as core part, which control the functioning of the equipments. A huge share of the precious metals is found to be present on printed circuit boards. ${ }^{11}$ On an average, one metric ton of PCBs contain between 80 to $1500 \mathrm{~g}$ gold and 160 and $210 \mathrm{~kg}$ of copper, these amounts are $40-800$ times more gold and 30-40 times more copper as compared to that are present in its ores. ${ }^{12} \mathrm{PCBs}$ also contain several other base, precious and rare earth metals. Thus, $\mathrm{PCBs}$ are referred as valuable secondary raw materials for these metals. ${ }^{13}$ They contain around 60 metals from the periodic table. ${ }^{14} \mathrm{PCBs}$ represents, $3 \mathrm{wt} \%$ of total e-Waste. Due to such a diversified and rich source of metals, PCBs are considered as urban mines to recover metals and illustrated as an attractive fraction for the metal extraction, recycling and recovery. PCBs are the flat surface, on which electric components such as conductor chips and capacitors are mounted (Figure 1). They act as a supporting material and to connect the chips using conductive path and signals through copper sheets present on the surface of PCBs, which are mainly laminated by plastics. ${ }^{12}$ There are different FR-standard (flame retardant) used in the manufacturing of different types of PCBs. Another name of PCBs is printed wiring boards (PWBs). PCBs have many diversified physical appearance in terms of shape and sizes. PCBs varies from less than $1-2 \mathrm{~cm}$ to as large as few tens $\mathrm{cm}$ depending upon the instruments or device in which they are used. PCBs of television, computer, mobile phone, tub lights and waste PCBs due to manufacturing defects are shown in Figure 1.They are also available with different colour coating like red, blue, and green and black some of these variation of PCBs are depicted in Figure 1. Wide variation in metal content are observed in PCBs based on types of PCBs and in which devices they are used, some of these metals variation of PCBs are depicted in Table $1 .{ }^{9}$ PCBs are found to be good source of copper, nickel and precious metals like gold as well as silver. However, the heterogeneous mixture of toxic and heavy metals makes them a challenging task from recovery point of view. So, in spite of high metals content and the toxic materials present in them, available environment friendly, economically viable separation techniques are limited for PCBs.

Table I Variation in metal content depending on types of e-Waste PCB ${ }^{9}$

\begin{tabular}{llllll}
\hline \multirow{2}{*}{ Metals } & \multicolumn{6}{l}{ Solubilised metals in various e-waste PCB (mg/g) } \\
& Mobile-phone & Computer & Television & LX & Tube-light \\
\hline $\mathrm{Cu}$ & 360 & 300 & 118.25 & 64.25 & 167.75 \\
$\mathrm{Zn}$ & 7.96 & 37 & 19.27 & 1.23 & 22.7 \\
$\mathrm{Ni}$ & 8.55 & 3.84 & 13 & 0.62 & 1.48 \\
$\mathrm{Al}$ & 6.66 & 45.93 & 56.27 & 14.28 & 53.22 \\
$\mathrm{~Pb}$ & 12.07 & 136.5 & 154.8 & 133.7 & 80.5 \\
$\mathrm{Fe}$ & 10.5 & 60.12 & 64 & 9.46 & 69.75 \\
$\mathrm{As}$ & 4.34 & 7.82 & 5.33 & 5.52 & 1.65 \\
$\mathrm{Cr}$ & 0.59 & 1.61 & 1.1 & 0.93 & 1.21 \\
$\mathrm{Au}$ & 0.1 & 0.14 & $\mathrm{ND}$ & $\mathrm{ND}$ & $\mathrm{ND}$ \\
$\mathrm{Ag}$ & 0.28 & 0.23 & 0.5 & 0.22 & 0.22 \\
$\mathrm{Pd}$ & 0.64 & 0.27 & 0.37 & 0.27 & 0.68 \\
$\mathrm{Cd}, \mathrm{Co}, \mathrm{Se}, \mathrm{K}$, & $\mathrm{BDL}$ & $\mathrm{BDL}$ & $\mathrm{BDL}$ & $\mathrm{BDL}$ & $\mathrm{BDL}$ \\
\hline
\end{tabular}

*ND=not detected; $\mathrm{BDL}=$ below detectable limit

\section{Microorganisms play role in metal extraction}

In $21^{\text {th }}$ century biohydrometallurgy is receiving significant attention in academic as well as applied research for the extraction of metals from solid wastes and concentrates. Microorganisms and their metabolites are playing pivotal role for solubilisation of metals in to aqueous phase from tailings, ores, concentrates and e-Waste. Microbial technologies are working at ambient temperature and pressure with mild conditions, thus they are easier to regulate and maintain. ${ }^{15}$ Initial knowledge about metal extraction mechanisms underlying microbial processes was first exploited at the sulphide mines where microorganisms are exploited for field scale process of metal extraction from low grade sulphide ores, which is referred as bioleaching/biomining. The first scientific evidence on the role of microorganisms in metal solubilisation was evident from isolation of acidophilic autotrophic iron and sulphur oxidising bacteria from acid mine drainage (AMD) by Colmer and Hinkle ${ }^{16}$ in 1947. In early 1950s Colmer has first time extracted copper from mine dump at Kennecott Copper Corporation through action of microorganisms. ${ }^{17}$ Nowadays, copper, gold and cobalt are extracted from their respective minerals at their industrial scale applying microbial technologies. Apart from copper and gold leaching encouraging results are achieved for the process in sulphides of $\mathrm{Cu}, \mathrm{Ga}, \mathrm{Mo}, \mathrm{Ni}, \mathrm{Pb}, \mathrm{Zn}$ and Platinum group of metals by biomining. ${ }^{18}$ The development of molecular biology techniques and its use in biomining field for the detection and identification of organisms have expanded our knowledge regarding metal microbial interaction and microorganisms playing significant role in metal extraction and recovery. Due to the advancement in techniques for the growth of fastidious microorganisms, identifications and use of molecular biology techniques, today it is clear that microorganisms belonging to all the three domains of life that is archaea, bacteria and eukaryote have potential role and application in biomining. ${ }^{19-21}$ The major microorganisms involved in metal extraction can be broadly grouped as iron and sulphur oxidizers, cynogenic organisms and organic acid producers, some detail of these organisms is shown in Table 2 and are discussed in the following sections. 


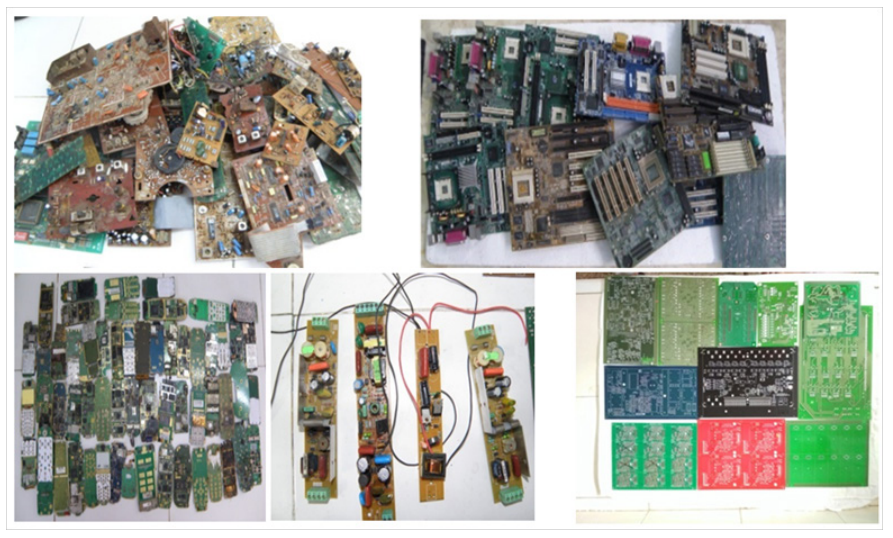

Figure I PCBs of television, computer, mobile phone, tub lights and assorted plates of different colours.

\section{Iron and sulphur oxidizer}

Iron and sulphur oxidizers are playing significant role in metal extractions from minerals and e-Waste. Among these, the wellknown and studied in detail are Acidithiobacillus ferrooxidans, Acidithiobacillus thiooxidans and Leptospirillum ferrooxidans. But these are not the only iron and sulphur oxidizing organisms known today which play significant role in metal solubilisation. Many other genera and species are now considered to be playing active role in metal mobilizations. Metal leaching bacteria are widely distributed in four phyla namely Proteobacteria, Nitrospirae, Firmicutes, and Actinobacteria. Acidithiobacillus, Acidiphilum, Acidiferrobacter, Ferrovum belongs to Proteobacteria, Leptospirillum is the member of Nitrospirae, Alicyclobacillus, Sulphobacillus are classified as Firmicutes, Ferrimicrobium, Acidimicrobium and Ferrithrix are Actinobacteria. Members of the domain archaea such as Sulfolobus, Acidianus, Metallosphaera, Sulfurisphaera are part of Crenarchaeota, whereas Ferroplasma acidiphilum, Ferroplasma acidarmanus belongs to Euryarcheaota. ${ }^{21}$ These organisms have diverse optimum temperature for their growth and activities and they are grouped based on their optimum temperature as mesophiles, moderate thermophiles and thermophiles. However, there are no distinct temperature divisions, for example Acidimicrobium ferrooxidans and Acidithiobacillus caldus remain active between temperature $25-55^{\circ} \mathrm{c}$, which is the temperature range of neither of mesophiles or moderate thermophiles. Based on preference of the substrates they are divided as iron oxidizers, sulphur oxidizers and third group, which oxidizes both iron and sulphur. Acidithiobacillus ferrooxidans is very versatile bioleaching bacteria, can live aerobically both by utilizing iron or reduced inorganic sulphur compounds. It also functions in the absence of air and show anaerobic growth by the oxidation of hydrogen and sulphur coupled with reduction of ferric iron. ${ }^{22}$ In the presence of high ferric/ferrous ratio Leptospirillum ferrooxidans and Leptospirillum ferriphillum over take Acidithiobacillus ferrooxidans and play dominant role in ferric iron generation to provide high ferric containing lixiviant, which play predominant role in extraction of metals from waste PCBs. In case of mineral either sulphur or pyrite are present, which served as an energy source for the iron and sulphur oxidizing organisms, in PCBs it is not the case. No required iron or sulphur is available as substrate. The bioleaching of metal sulphides by Acidithiobacillus ferrooxidans is described by two mechanisms, direct- and indirect mechanism. However, it is accepted that direct mechanism does not exists and sole mechanisms of metal extractions is referred as indirect mechanism, however, now bioleaching is more clearly explained by the more acceptable terminology, contact and noncontact mechanisms. ${ }^{23,24}$ For the contact mechanisms the production of extracellular polymeric substances (EPS) is very essential for the contact and filling up the space between the cell wall and surface of the substrate. In e-Waste, specifically PCBs metals are not present in the form of metal sulphides, but they are present at zero valent metal, as for example $\mathrm{Cu}^{0}, \mathrm{Zn}^{0}, \mathrm{Ni}^{0}$ etc. Thus, biologically produced ferric and/ or protons from ferrous, sulphur or reduced sulphide compounds are responsible for conversion of insoluble $\mathrm{Cu}^{0}, \mathrm{Zn}^{0}, \mathrm{Ni}^{0}$ to water soluble $\mathrm{Cu}^{2+}, \mathrm{Zn}^{2+}$ and $\mathrm{Ni}^{2+}$ as shown in following equation (Eq.2-4)(25)

$$
\begin{aligned}
& 4 \mathrm{Fe}^{2+}+\mathrm{O}_{2} \stackrel{\mathrm{Fe} \text {-oxidizer }}{\longrightarrow} 4 \mathrm{Fe}^{3+}+\mathrm{H}_{2} \mathrm{O} \\
& 2 \mathrm{Fe}^{3+}+\mathrm{Cu}^{0} \rightarrow 2 \mathrm{Fe}^{2+}+\mathrm{Cu}^{2+} \quad \Delta \mathrm{G}=-82.9 \mathrm{~kJ} / \mathrm{mol} \\
& 2 \mathrm{Fe}^{3+}+\mathrm{Zn}^{0} \rightarrow 2 \mathrm{Fe}^{2+}+\mathrm{Zn}^{2+} \quad \Delta \mathrm{G}=-295.4 \mathrm{~kJ} / \mathrm{mol} \\
& 2 \mathrm{Fe}^{3+}+\mathrm{Ni}^{0} \rightarrow 2 \mathrm{Fe}^{2+}+\mathrm{Ni}^{2+} \quad \Delta \mathrm{G}=-196.6 \mathrm{~kJ} / \mathrm{mol} \\
& \mathrm{S}^{0}+105 \mathrm{O}_{2}+\mathrm{H}_{2} \mathrm{O} \stackrel{\text { microbes}}{\longrightarrow} \mathrm{SO}_{4}^{2-}+2 \mathrm{H}^{+} \\
& 2 \mathrm{Cu}^{0}+4 \mathrm{H}^{+}+\mathrm{O}_{2} \rightarrow 2 \mathrm{Cu}^{2+}+2 \mathrm{H}_{2} \mathrm{O}
\end{aligned}
$$

As can be seen from the equations (Eq.5,6), solubilisation of copper from PCBs in the absence of iron takes place through oxidation of elemental sulphur, which provides required protons for copper solubilisation. However, in this case the presence of molecular oxygen is required. The delta energy showed in various equations indicates thermodynamic feasibility of the reactions. The most interesting and useful part is, all these reactions are taking place at ambient temperature and pressure under mild acidic environment, which leads to eco-friendly environment sustainable microbial technology for metal extraction from waste PCBs. Major microorganisms involved in metal extraction from e-Waste, substrate used by them, metabolic products produced and metals solubilised are listed in Table 2 .

\section{Cyanogenic organisms}

Use of cyanidation process is known for extraction of gold and silver from gold containing minerals using alkaline condition since 1898. ${ }^{26}$ Cyanide forms water soluble complex with gold and it is responsible for gold extraction. The use of biogenic cyanide provides an alternative, eco-friendly gold extraction processes, which can be referred alkaline bioleaching or heterotrophic bioleaching process. Hydro cyanide $(\mathrm{HCN})$ is generated by diverse heterotrophic organisms. The major bacteria reported for $\mathrm{HCN}$ production are Chromobacteriun violaceum, Pseudomonas fluorescens, Pseudomonas plecoglossicida and Pseudomonas aeruginosa (Table 2). Fungi like Marsmius oreades species of clitocyde and polysphrous are also reported for $\mathrm{HCN}$ production. The enzyme involved for gold recovery is called as HCN synthase. Normally HCN is produced between the end of exponential phase and early stationary phase during the growth of $C$. violaceum and in the beginning of stationary phase by Pseudomonas. In case of Chromobacterium the produce HCN is detoxified during the late stationary phase by transforming it to $\beta$-cynoalanine. ${ }^{27}$ The dissolution of gold can be express as following anodic (Eq. 6) and cathodic (Eq. 7) reactions.

$$
\begin{aligned}
& 4 \mathrm{Au}+8 \mathrm{CN} \rightarrow 4 \mathrm{Au}(\mathrm{CN})^{2-}+4 e^{-} \\
& \mathrm{O}_{2}+2 \mathrm{H}_{2} \mathrm{O}+4 e^{-} \rightarrow 4 \mathrm{OH}^{-}
\end{aligned}
$$




$$
4 \mathrm{Au}+8 \mathrm{CN}+\mathrm{O}_{2}+2 \mathrm{H}_{2} \mathrm{O} \rightarrow 4 \mathrm{Au}(\mathrm{CN})^{2-}+4 \mathrm{OH}^{-}
$$

The overall reaction is known as Elsner's equation (Eq. 9). In case of PCBs, before giving the cyanogenic bacterial treatment it is essential to treat PCBs with iron and sulphur bacteria for removal of copper and other metals, otherwise these metals interfere in the process of gold extractions by consuming the HCN. The presence of oxygen plays an important role in the dissolution of gold, which is normally consumed rapidly during the growth phase of organisms resulting in high decrease in solubilisation of gold.

\section{Fungi}

Several fungi are reported to grow at low $\mathrm{pH}$, low temperature and in the presence of metal ions and contaminants. Fungi such as Aspergillus niger and Penicillium simplicissimum produce organic acids such as citric acid, oxalic acid, Malic acid and gluconic acid. These acids serve as lixiviant and help in solubilisation of various base metals from e-Waste (Table 2). Considering the ability of such fungi, which modify metal speciation and increase mobility of the metals, they could offer a potential alternative method of metal extraction from e-Waste. ${ }^{28}$ Moreover, fungi can attack on mineral surface by proton production by acidolysis. ${ }^{25,29}$ Compared to iron and sulphur bacteria, metal leaching is possible by these fungi at less acidic $\mathrm{pH}$, which further minimize environmental risk. ${ }^{30}$ Addition of some of these organic acids during metal mobilisation by iron oxidizing bacteria favour better metal solubilisation and keeping ferric iron for more time in solution form.

Table 2 Major microorganisms and metal extraction mechanisms

\begin{tabular}{|c|c|c|c|}
\hline Name of organisms & $\begin{array}{l}\text { Source of energy/substrate } \\
\text { used }\end{array}$ & Metabolic product as lixiviant & Metal extracted \\
\hline \multicolumn{4}{|l|}{ Iron oxidizers } \\
\hline $\begin{array}{l}\text { Acidithiobacillus } \\
\text { ferrooxidans }\end{array}$ & Ferrous sulphate & Ferric sulphate & $\mathrm{Cu}, \mathrm{Zn}, \mathrm{Ni}, \mathrm{Pb}, \mathrm{Cd}$ \\
\hline \multicolumn{4}{|l|}{ Leptospirillum ferrooxidans } \\
\hline \multicolumn{4}{|l|}{ Leptospirillum ferriphillum } \\
\hline \multicolumn{4}{|l|}{ Sulphur oxidizers } \\
\hline $\begin{array}{l}\text { Acidithiobacillus } \\
\text { thiooxidans }\end{array}$ & $\begin{array}{l}\text { Sulphur and/ reduced sulphur } \\
\text { compound }\end{array}$ & $\begin{array}{l}\text { Sulphuric acid/ oxidized form of sulphur } \\
\text { compound }\end{array}$ & $\mathrm{Cu}, \mathrm{Zn}, \mathrm{Ni}, \mathrm{Al}$ \\
\hline \multicolumn{4}{|l|}{$\begin{array}{l}\text { Sulphobacillius } \\
\text { thermosulphidooxidans. }\end{array}$} \\
\hline \multicolumn{4}{|l|}{ Sulpholobus spp. } \\
\hline \multicolumn{4}{|l|}{$\begin{array}{l}\text { Cyanogenic } \\
\text { organisms }\end{array}$} \\
\hline $\begin{array}{l}\text { Chromobacterium } \\
\text { violaceum }\end{array}$ & Glycine & $\mathrm{HCN}$ & $\mathrm{Au}, \mathrm{Ag}, \mathrm{Pd}, \mathrm{Pt}$ \\
\hline \multicolumn{4}{|l|}{ Pseudomonas aeruginosa } \\
\hline \multicolumn{4}{|l|}{ Pseudomonas florescence } \\
\hline \multicolumn{4}{|l|}{ Marsmius oreades } \\
\hline \multicolumn{4}{|l|}{$\begin{array}{l}\text { Organic acids } \\
\text { producers }\end{array}$} \\
\hline Aspergillus niger & Carbohydrate (glucose, sucrose) & Citric, oxalic, gluconic and malic acid & $\begin{array}{l}\mathrm{Cu}, \mathrm{Zn}, \mathrm{Ni}, \mathrm{Pb}, \mathrm{V}, \mathrm{Mo}, \mathrm{Al}, \\
\mathrm{Co}, \mathrm{Li}\end{array}$ \\
\hline Penicillium simplicissimum & & & \\
\hline
\end{tabular}

\section{Bioleaching process}

Metal bioextraction from e-Waste is performed by one step bioleaching, two step bioleaching and spent medium process. E-Wastes are principally different from sulphide minerals. In e-Waste, metals are present in their zero valent form where as in case of sulphide mineral, they are present in the form of metal sulphides along with pyrite or sulphur. Metal sulphides, pyrite and/or sulphur are energy source for iron and sulphur oxidizing organisms. During one step process, added inoculum in the leaching system utilize these as substrates and constantly generate ferric and/or proton as lixiviants. These lixiviants act upon metal sulphides and metal get solubilised. In case of e-Waste no such substrates or energy sources are available, so it is necessary to add ferrous iron, pyrite or sulphur in the leaching system from, which the organism generates required lixiviants.

\section{One step bioleaching process}

In case of one step bioleaching process the inoculum from the exponential phase is added in the suitable leaching medium along with e-Waste and process is continued for generation of ferric iron 
or proton, which gradually solubilise metals at describe in Equations 1-4. The presence of toxic organic compounds, metals present or generated during the process exert inhibitory effects on organisms. ${ }^{13}$ Thus, growth and activity of inoculum get retarded or even inhibited. Such inhibitory effects restrict the one step bioleaching process to operate at low pulp density. As per the available data in the literature, most of the processes are carried out in the range of $1-5 \%(\mathrm{w} / \mathrm{v})$ e-Waste or at the most at $10 \%(w / v)$ e-Waste. ${ }^{31}$ Addition of low pulp density results in low concentration of metal extraction in the medium. Moreover, in one step process it is difficult to provide optimum conditions simultaneously both for the growth of the organisms and metal extraction, which is also responsible for low metal extraction rates in this process.

\section{Two step bioleaching process}

In two step bioleaching process, desired organisms are grown in their respective medium under their optimum growth conditions as first step of the process. When the maximum growth of the organism and lixiviant (ferric, proton, cyanide) achieved e-Waste is added at the second step of the process. Two-step bioleaching process minimize inhibition of the organisms due to the toxicity of e-Waste and it also provides optimum conditions both for the growth in the first step and for metal solubilisation in the second step. Two-step bioleaching process is found to be more attractive as it results in faster and higher metal extraction. ${ }^{32}$ Moreover, it is also possible to run the process at high pulp density as compared to one step bioleaching process. During the second step biogenerated ferric iron is consumed in metal extractions and it is converted in ferrous iron. The produced ferrous iron is transferred to first step of the process where it can be re-biooxidized and ferric iron is produced, which once again serves as lixiviant for solubilisation of metals. In case of two-step process large quantity of ferric iron/proton/cyanides are available when e-Waste is added, which immediately react with e-Waste and metals get solubilised at possible fastest rate.

\section{Spent medium process}

In case of spent medium process as described in two-step process, organisms are allowed to grow under optimum conditions to get maximum growth and lixiviants. After growth, organisms are removed by centrifugations and in collected spent medium, e-Waste is added. In case of gold extraction, spent medium process is found to be more useful as it results in higher gold extractions as compared to two-step process. Moreover, the organisms are removed in this process from the spent medium; they will not use the oxygen that is supplied for the extraction of gold, therefore more oxygen is available for gold leaching as compared to two-step process. Further, cyanogenic bacteria produce $\mathrm{HCN}$ in late logarithmic or early stationary phase and if the organisms are not removed they transfer produced $\mathrm{HCN}$ in to $\beta$-cyno-alanine. Thus, available HCN gets reduced, which is also responsible for low gold extraction in two-step process as compared to this process. Such negative effect may not be occurring in case of ferric iron or proton production system. Thus, two-step process may be the process of choice for metal extraction from e-Waste using iron or sulphur oxidizing organism, whereas use of spent medium method may be preferred for gold extraction with cynogenic bacterial process.

\section{Factors influencing e-Waste bioleaching}

Wide varieties of organisms are used for metal extraction from e-Waste. The bioleaching process is mainly governed by the production of ferric iron/protons/organic acids and HCN. Irrespective of the lixiviant and the organisms used for the bioleaching process the major factors, which affect metal ion extraction are $\mathrm{pH}$, temperature, dissolved oxygen, pulp density, concentration of iron/HCN, type of the culture, medium, particle size of the e-Waste and addition of surfactants and complexing agents. ${ }^{33}$ All the three groups of organisms are found to be more effective under aerobic conditions, thus aeration or agitation play significant role in metal extractions. Metal extractions mediated by iron and sulphur oxidizers as well as fungi require acidic $\mathrm{pH}$ on the other hand cyanogenic bacteria found to be more active in metal extractions at alkaline $\mathrm{pH}$ preferably $\mathrm{pH}$ above 9.0 so produced HCN transferred to cyanide and not lost as vapour, thus results in more metal extraction. Increasing pulp density is desired for economic extractions of metals but it exert inhibitory effects on the organisms, which restrict the process above certain pulp density. Most of the reported e-Waste bioleaching processes have used less than $10 \% \mathrm{w} / \mathrm{v}$ pulp density. Shah et al., ${ }^{33,34}$ have studied the process at $15 \% \mathrm{w} / \mathrm{v}$ and higher pulp density. The restriction of pulp density may be over come to certain extend with the implementation of two-step bioleaching or spent medium bioleaching process. Positive influence of addition of surfactant and complexing agent for metal extraction from e-Waste is highlighted by Lan et al., ${ }^{33,35}$ have also reported effect of individual chelating agents and pointed out the benefit of ethylene diamine disuccinic acid (EDDS) as compared to use of ethylene diamine tetra acetic acid (EDTA). Influence of these additives has different preference with relation to the target of metal for solubilisation. In the process, ferric iron act as lixiviant and chelating agent act as ligand, which form complexation of ferric-chelate-metal that helps in keeping more ferric iron in solution, thus resulting in better extractions ${ }^{36}$ Better metal extraction is reported with smaller particle size, however, we have notice the findings may not remain true in certain e-Waste and critical selection of particle size is essential. E-Waste bioleaching is mainly controlled by the production of lixiviant, thus concentration of ferric iron, organic acids, $\mathrm{HCN}$, and/or protons are playing significant role, thus it is preferred to keep these lixiviants at the desired optimum concentration to achieve faster and higher metals extraction. ${ }^{37}$

Recently bioleaching processes from e-Waste are studied with some modifications for better metal extractions. One-step process is used with some modification, where the total pulp density is not added as one lot, but it is added in fractions as 2/3/4 lots (fed batch process). Such fraction addition result in higher metal extractions as compared to addition in one lot. ${ }^{33}$ Normally possible small size of e-Waste is preferred for high metal extraction, but it requires grinding, which increase process cost, generate air pollution, make solid separation difficult after leaching process, generate more sludge. If PCBs are used without grinding it give more metal extractions and reduce many of the indicated problems, which are resulted due to the use of fine particles of e-Waste for the process (unpublished data). When large PCBs are used without grinding, after leaching process the PCBs glass epoxy plates can be used for various applications. Problems raised due to use of smaller particles of e-Waste may be reduced by the applications of membrane technology. Author have studied cheaper membranes prepared from cloths for entrapping ground waste during bioleaching showed better metal extraction and very easy separation of leached e-Waste solids from the solution (filed patent).

\section{Recovery of metals from leachate}

Bioleaching of e-Waste generate metal loaded aqueous solutions. These metals are positively charged and bacterial cell wall is 
negatively charged, thus almost all bacterial biomasses are used as biosorbent for the sorption of metals. Bacterial, yeast, fungal and plant biomass live or dead are used for metal recovery from solution. Several mechanisms and many types of biomass are involved in metal recovery from metal loaded solution. It is very wide topic and it cannot be covered in this chapter. This topic need separate chapter to give proper justification.

\section{Future aspects}

Biomining is a very old process to extract metals from ore and concentrates. It is a green technology from the environmental point of view. However, research is limited in e-Waste bioleaching field as compared to other discipline mainly because of the handling of a live system is difficult as compared to chemical and mechanical treatments. The prevailing e-Waste treatment methods are still harmful and toxic to human as well as the biotic and abiotic surroundings. Various technologies for metal extraction from e-Waste are developed and implemented. Amongst these biohydrotechnology seems to be safe and acceptable technique nevertheless, the gaps in the study still prevail and needs to be connected. The major problems are, this method can tackle a small amount of e-Waste and the organisms used in the process failed to remain viable for a longer time due to the toxicity of $\mathrm{e}$-Waste. So, there is an urgent need to focus on constraction of better strain, development of new strain, process optimization, scale-up of the current process for e-Waste management and treatment. Thus, the field need be more focusing on various interdisciplinary subjects such as microbiology, metallurgy, engineering, and biotechnology.

\section{Conclusion}

Diversified toxic material present in e-Waste needs to be efficiently remediated from the sites where they disposed to minimize their effect on the environment. Microbiological hybrid processes have the future to reduce the toxicity associated with e-Waste hazards. Presence of organic pollutants and coating of colour epoxy layers on metals need to be removed as pre-treatment to make metals available for microbial attack so they can be extracted at much faster rate and in more amounts. However, the efficiency of biological treatments would be enhanced if it is used with a combination of different methods such as with nano particles or with some non-polluting biodegraded agents. As well as the need to bridge knowledge gap through further efforts on reducing, reuse and recycling strategy.

\section{Acknowledgements}

The authors acknowledge the financial support from the UGC New Delhi, for Emeritus Professor Fellowship to S.R.Dave.

\section{Conflict of interest}

Author declares that there is no conflict of interest.

\section{References}

1. Tansel B. From electronic consumer products to e-waste: Global outlook, waste, quantities, recycling challenges. Environ Int. 2017;98:35-45.

2. Bhattacharya A, Khare SK. Sustainable options for mitigation of major toxicants originating from electronic waste. Curr Sci. 2016;111(12):1946-1953.

3. Sodha AB, Qureshi SA, Khatri BR, Tipre DR, Dave SR. Enhancement in iron oxidation and multi metal extraction from waste television printed circuit boards by iron oxidizing Leptospirillum ferriphilum isolated from coal sample. Waste Biomass Valor; 2017.
4. Cui H, Anderson CG. Literature Review of hydrometallurgical Recycling of printed circuit boards (PCBs). J Adv Chem Eng. 2016;6(1):1-11.

5. Kaya M. Recovery of metals and non-metals from electronic waste by physical and chemical recycling process. Waste Manag. 2016;57:64-90.

6. Shah M, Tipre D, Dave S. Chemical and biological processes for multimetal extraction from waste printed circuit boards of computers and mobile phones. Waste Manag Res. 2014;32(11):1134-1141.

7. Awasthi A, Zeng X, Li J, Environmental pollution of electronic waste recycling in India: A critical review. Environ Poll. 2016;211:259-270.

8. Awasthi A, Li J. Management of electrical and electronic waste: A comparative evaluation of China and India. Renew Sustain Energy Reviews. 2017;76:434-447.

9. Dave SR, Shah MB, Tipre DR. E-waste: metal pollution threat or metal resource? J Adv Res Biotechnol. 2016;1(2):1-14.

10. European Union. Waste Electronic and Electrical Waste (WEEE). Directive, Brusseles, 2000.

11. Kiddee P, Naidu R. Electronic waste management approaches: an overview. Waste Manag. 2013;33(5):1237-1250.

12. Hadi $\mathrm{P}, \mathrm{Xu} \mathrm{M}$, Lin CSK, et al. Waste printed circuit board recycling techniques and product utilization. J Hazard Meter. 2015;283:234-243.

13. Pradhan J, Kumar S. Metals bioleaching from electronic waste by Chromobacterium violaceum and Pseudomonas sp. Waste Manag Res. 2012;30(11):1151-1159.

14. Veit HM, Bernardes A. Electronic waste, in: topics in mining, metallurgy and materials engineering. 2017.

15. Erüst C, Akcil A, Gahan CS, et al. Biohydrometallurgy of secondary metal resources: A potential alternative approach for metal recovery. $J$ Chem Tech Biotech. 2013;88(12):2115-2132.

16. Fonti V, Amato A, Beolchini F. Urban Biomining: New challenges for a successful exploitation of WEEE by means of biotechnological approach, In: Microbiology for Minerals, Metals, Materials and the Environment, CRC; 2015:329-358.

17. Zimmerley SR, Wilson DG, Prater JD. Cyclic leaching process employing iron oxidizing bacteria. U.S. Patent 2;1958:829-964.

18. Lee JC, Pandey BD. Bio-processing of solid wastes and secondary resources for metal extraction-A review. Waste Manag. 2012;32(1):3-18.

19. Norris PR. Acidophile diversity in mineral sulfide oxidation. In: Biomining. 2007:199-216.

20. Ehrlich HL. Past, present and future of biohydrometallurgy. Hydrometallurgy. 2001;59(2-3):127-134.

21. Vera M, Schippers A, Sand W. Progress in bioleaching: fundamentals and mechanisms of bacterial metal sulfide oxidation -Part A. Appl Microbiol Biotechnol. 2013;97(17):7529-7541.

22. Johnson DB, Geomicrobiology of extremely acidic subsurface environments. FEMS Microbiol Ecol. 2012;81(1):2-12.

23. Rawlings DE, Heavy metal mining using microbes. Annu Rev Microbiol. 2002;56:65-91 (2002).

24. Rohwerder T, Sand W. Oxidation of inorganic sulphur compounds in acidophilic prokaryotes. Eng Life Sci. 2007;7(4):301-309.

25. Chauhan G, Jadhao PR, Pant KK, et al. Novel technologies and conventional processes for recovery of metals from waste electrical and electronic equipment: Challenges \& opportunities- A review. J Environ Chem Eng. 2018;6(1):1288-1304.

26. Smith A, Mudder T. Chemistry and Treatment of Cyanidation Wastes. Mining Journal Books Ltd; UK.1991:345. 
27. Knowles CJ, Bunch AW. Microbial cyanide metabolism. Adv Microbial Physio. 1989.27:73-111.

28. Bosecker K. Bioleaching: Metal solubilization by microorganisms. FEMS Microbiol Rev. 1997;20(3-4):591-604

29. Brandl H, Lehmann S, Faramarzi MA, et al. Biomobilization of silver, gold, and platinum from solid waste materials by $\mathrm{HCN}$-forming microorganisms. Hydrometallurgy. 2008;94(1-4):14-17.

30. Sabra N, Dubourguier HC, Hamieh T. Fungal leaching of heavy metals from sediments dredged from the Deûle canal. Adv Chem Eng Sci. 2012;02(01):1-8.

31. Liang G, Ting J, Liu W, Zhou Q. Optimizing mixed culture of two acidophiles to improve copper recovery from printed circuit boards (PCBs). J Hazard Mater. 2013;250-251:238-245.

32. Sand W, Gehre T, Jozsa PG, et al. Biochemistry of bacterial leachingdirect vs indirect bioleaching. Hydrometallurgy. 2001;59:159-175.
33. Shah M, Tipre D, Purohit M, et al. Development of two-step process for enhanced biorecovery of $\mathrm{Cu}-\mathrm{Zn}-\mathrm{Ni}$ from computer printed circuit boards. J Biosci Bioeng. 2015;120(2):167-173.

34. Ilyas S, Lee J, Kim B. Bioremoval of heavy metals from recycling industry electronic waste by a consortium of moderate thermophiles: process development and optimization. J Clean Prod. 2014;70:194-202.

35. Lan Z, Hu Y, Qin W. Effect of surfactant OPD on the bioleaching of marmatite. Miner Eng. 2009;22(1):10-23.

36. Vlivainio K. Effects of iron (III) chelates on the solubility of heavy metals in calcareous soils. Environ Pollut. 2010;158(10):3194-3200.

37. Pant D, Joshi D, Upreti MK, et al. Chemical and biological extraction of metals present in e-waste: a hybrid technology. Waste Manag. 2012;32(5):575-583 